\title{
AN ANALYSIS OF TEACHERS' CLASSROOM MANAGEMENT IN TEACHING ENGLISH
}

\section{Ratu Amalia Mudianingrum, Sutrisno Sadji Evenddy, Rosmania Rima ${ }^{1}$}

${ }^{1}$ English Education Study Program of Teacher Training and Education Faculty, Universitas Sultan Ageng Tirtayasa

\section{ARTICLE INFO}

Keywords:

Descriptive Analysis

Classroom Management Strategy

\begin{abstract}
Classroom Management is a multifaceted concept and views about classroom and its styles can be categorized in various ways. This study focused on the classroom itself. Therefore, this study was intended to describe the classroom management and the use of teaching learning strategy at the eight grade students in SMPN 05 Kota Serang. This study was also aimed to give some contributions concerning the Classroom Management Strategy and the students' participation on the use of the strategy in teaching learning process in the class. This study is qualitative research. The writer had chosen two english teachers who taught the eighth grade students of SMPN 05 Kota Serang in the academic year of 2017/2018 as the subject. The writers describe the process of organizing teaching and learning process in SMPN 05 Kota Serang by applying interview and observation to the teachers. The writers could conclude that $\mathrm{T} 1$ applied $72 \%$ and $\mathrm{T} 2$ applied 70\% classroom management strategy in their classroom. They applied the classroom strategies from opening to closing activities, used seating arrangement during the teaching learning process, explained the material well, gave motivation, had positive attitude and built the relationship with students.
\end{abstract}

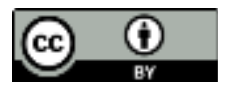

This is an open access article distributed under the terms of the Creative Commons Attribution 4.0 International License, which permits unrestricted use, distribution, and reproduction in any medium, provided the original work is properly cited. @ 2019 Ratu Amalia Mudianingrum, Sutrisno Sadji Evenddy, Rosmania Rima

\section{INTRODUCTION}

In most schools and for most teachers, challenging behavior can generally be understood as something that either interferes with the safety or learning of the student or other students or interferes with the safety of school staff. Teacher as a knowledge transferer to students is a prospect nation who can make nation ideal comes true. In teaching, all materials should be prepared, like learning material, learning media, and activities in exploration, elaboration, and confirmation. Good and Brophy (2003:48) state that teachers are not aware of everything that goes on in the classroom, and this lack of awareness may interfere with their effectivity.

\footnotetext{
1 Corresponding author's address: English Education Study Program of Teacher Training and Education Faculty, Universitas Sultan Ageng Tirtayasa, Banten, Indonesia

e-mail: ratuamelia27@gmail.com, ssadjievenddy@gmail.com, rosmania@untirta.ac.id
} 
A teacher is required not only skilled in the mastery of the material, but most of the teachers are also required to be skilled in encouraging their students to learn. In other words, a teacher is expected to help students in the learning process so that they can build up an awareness in view of the importance of learning a learning material presented by the teacher, which in turn can provide a change in the behavior of the students themselves. The education process takes place if there is an active interaction between students, teachers, teaching materials and learning environment.

Junior high school is a period when children grow up physically and psychologically. They always feel curious about what happened around supported by all information media which are easy to access, and absolutely not all information give positive impact on them. It is the one of teacher's duty to place and direct students to the positive activities, and school is the right place. School and class situation will be more fun if they are supported by good classroom management. The students in eighth grade are more active, grow emotionally and physically fast, so that their attitude easy to change or labile than in the seventh period, because in the seventh grade they still shy and afraid to open themself, so do in the ninth grade, because in this grade they concern more on National Examination. There are some reasons why the researchers chose SMP N 5 Kota Serang as the research setting such as; this school is one of school which has good administration and infrastructures in teaching learning process and every teacher have different strategies in managing the class. This school has good facilities, there are equipped a language laboratory, science laboratory, computer laboratory and library, canteen and etc. Based on the reason above, the researchers is interested in conducting the research entitled "An Analysis of Teacher's Classroom management in teaching English at SMPN 5 Kota Serang."

\section{The Notion of Classroom Management}

Marzano (2003:31) in Garret (2014), classroom management is consistently identified as an important factor in student learning. Meanwhile, Wong and Wong (1998) stated that classroom management includes all of the things that a teacher must do towards two ends, namely; to foster student involvement and cooperation in all classroom activities; and to establish a productive working environment. In other words, it can be stated that classroom management is any action which the teacher uses for building a good collaboration of social interaction, active engagement in learning, and motivation in the teaching and learning process. Classroom management is a multifaceted concept and views about classroom and its styles can be categorized in various ways. Writers categorize different classroom management approaches based on different aspects of classroom management. Nevertheless, most generally degree of teacher-control over classroom issues and students take as the organizer for classification by researchers.

\section{The areas of responsibility of classroom management.}

Burden (2000:218) state that the order means that students are following the actions necessary for a particular classroom event to be successful; students are focused on the instructional task and are not misbehaving. There are several areas of responsibility for the classroom management. Burden (2000:13) stated that an effective classroom management handles the following seven areas of responsibility:

a. Select a philosophical model of classroom management and discipline.

b. Organize the physical environment.

c. Manage student behavior.

d. Create a respectful, supportive learning environment.

e. Manage and facilitate instruction.

f. Promote classroom safety and wellness.

g. Interact with colleagues, families, and others to achieve classroom management objectives.

Certain models of classroom management have been proposed by some educators, such as teaching with love and logic, cooperative discipline, discipline with dignity, and assertive discipline. Teachers really need these theoretical models since they offer a basis for analyzing, understanding, and managing the students and the teachers' behavior. The teacher should select a 
philosophical model that is consistent with their beliefs. The technique which is used to manage students' behavior should be consistent with the belief about students learn and develop.

The instruction and the order in the classroom are affected by the way desks, tables, and other class materials arrangements. The teacher needs to organize several aspects of the physical space to create an effective learning environment. A classroom needs guidelines to promote the order and to provide conducive learning environment. Burden and Byrd (2010:219) stated that rules and procedures support teaching and learning and provide students with clear expectations and welldefined norms. Students also need to feel physically and emotionally safe before they can give full attention to the instructional tasks.

Some aspects which contribute to classroom safety and wellness, such as strategies in managing student behavior, creating a supportive classroom, and managing and facilitating instruction needs to be cope by the teacher. However, sometimes teacher needs to take actions for solving problems and conflicts that threaten classroom order and the learning environment.

The Effective Classroom Management

Garret (2014:3) stated that classroom management as a process consisting of the following five key areas: organizing the physical design of the classroom, establishing rules and routines, developing caring relationships, implementing engaging and effective instruction, and addressing discipline issues.

a. Physical design of the classroom. The classroom environment has proven to change and influence behaviors among students. The design of the classroom allows for some activities to take place and for other to not. It is important that teachers take into consideration the influence their classroom arrangement can make on their students. The environment of a classroom sends out symbolic messages to those who enter the classroom. At times, these messages do not send the right message to the students. The environment should reflect the beliefs and values of the teacher. Therefore, it is vitally important that teachers see what message their classroom sends out. The physical design lies in how the classroom is laid out, where the students' desks are, where the teacher's desk is, where learning centers and materials are located, where heavily used items such as the pencil sharpeners are, and so on.

b. Rules and routines. Classroom rules, though, are generally about overall conduct, whereas routines are much more specific to certain tasks and usually provide some direction about how these tasks should be accomplished, rather than seeking to prevent a particular type of behavior. They are both essential components of an effective classroom management plan and go a long way with respect to developing an environment conducive to learning. In addition to rules, routines are essential for the overall fluidity of the classroom. They show students how to carry out common tasks in an efficient, orderly manner. Without routines, tasks that should be accomplished almost seamlessly throughout the day will take more time to accomplish, thereby reducing the amount of time available for instruction. Most classrooms have many different needed routines, and it is critical for teachers to work out what these will be (Emmer \& Gerwels, 2006). Most routines fall into three broad categories: movement routines, lessonrunning routines, and general procedures. Teachers establish class rules and routines (such as handing back papers and taking attendance) to keep the class activities running smoothly with as little disruption and loss of time as possible.

c. Relationships. The idea of developing caring relationships is often overlooked during conversations about classroom management. Effective classroom managers develop caring, supportive relationships with students and parents and promote supportive relations among students.

d. Engaging and motivating instruction. The fourth component of classroom management is engaging instruction, which involves using instructional techniques that increase students' motivation and interest in learning. It is imperative that teachers understand that there is a 
reciprocal relationship between engaging, motivating instruction and effective classroom management. This means that, on the one hand, the more engaging the instruction is, the fewer behavioral issues will arise, because students are actively engaged, interested, and motivated in the lesson (Savage \& Savage, 2010; Weinstein \& Romano, 2014). On the other hand, there are some issues of classroom management that must be attended to so that a teacher can implement an engaging and motivating lesson. Effective managers develop instruction that engages learners, and they carefully plan their instruction so that each learning activity is well organized and runs smoothly.

e. Discipline. Discipline is the required action by a teacher toward a student (or group of students), after the student's behavior disrupts the ongoing educational activity or breaks a preestablished rule created by the teacher, the school administration or the general society. Discipline, guiding children's behavior, or setting limits are all concerned with helping children learn how to take care of themselves, other people, and the world around them. Discipline revolves around teacher actions focused on preventing and responding to students' misbehavior. Discipline does not only mean punishment, nor does it only mean the actions that teachers take after misbehavior occurs. Discipline also includes teacher actions that prevent misbehavior.

\section{Teaching strategy of Classroom management}

Classroom management is a very important aspect of teaching these writers collects data within the strategy of the management class that teaching is a pleasure and the students will be enthusiastic in learning. According to Burden (2010:75) this data is designed to give you a few tips that will help the author with class management strategies.

a. Get set up. The teacher has to be preparation, when the teacher wants to teach the things that need to be prepared is the learning material and learning implementation plan that will be submitted. As well as the teacher should plan and develop daily schedules as well as lesson plans are closely aligned on the provisions provided by the school district. This plan should be Universal to the needs and learning styles of each students in the class, in other words students are visual learners should be given lessons and activities that suit their learning styles, students who study hearing loss should receive instruction in these areas, students who need extra time to get that time, students who Excel should have additional tasks that they can independently resolve and so on. When the teachers prepare to teach in school classrooms then the students will have an exciting and productive day in following lessons each day.

b. Make the room attractive. Teachers must work to have an attractive and conducive spaces as well as students can appreciate and enjoyas well as creating a clean and comfortable room for them to learn. For example in teaching using slides, pictures or games, make a schedule for the class and teacher cleansing have to apply the schedule in particular teaching. Do this thing can produce students to be more creative, innovative and keep them happy will be a lesson that teachers pass.

c. Set classroom rules. Rule in class is very necessary because as control and guide in teaching. so that in teaching can be a maximum and conducive school classrooms; , as well as teachers involve students in designing the rules and those who will be running it so as to allow students to work discipline in running the rules. After the rules is made, and then make it as responsibility, all students who violate or not to see that the rules are followed properly or not. As well as give reward students who run the rules properly. This will encourage other students to continue to follow the rules as well as motivate students who are not successful enough to earn the reward at a later date.

d. Be enthusiastic about the lessons. When the teacher gives the lesson have earned more interactive with the students and engage them to participate and can understand. Develop methods that teacher create and encourage all students to participate in the lessons and if 
students gave a wrong answer, the task of the teacher is to encourage and help them to succeed by helping them with the correct answer and give instructions, ask questions and answer appropriately, make sure that the teachers always thank for the student to their participation in the following lesson in school classrooms. Please remember to give students sufficient wait time for answering questions because the students are all different and some need more time than others. The process never wanted to shut the students remain the answers always flows and continue to encourage and bring out the best in them.

e. Be fair with the students. As a teacher it is necessary for teaching to be fair to all of the students. Make a point to always hear students out and treat each one of the pupils with dignity and respect. Don't make differences in them and give the ones that appear a bit disobedient as much respect as teach give those who present themselves respectfully all of the time. They will all love and appreciate teacher for this attitude of being fair to all students.

f. Keep students of records. When kids do their jobs, then their work should be assessed and recorded in grade book. It provides its own entry for the students, as well as provides gifts and good judgment to students if they can behave well in class. It also lets the kids know that the teacher has a specific meaning and they should live it well, because it aims for them salve and explore by helping them to understand the concepts being taught. As the given task can be rated as class assignments by students' under the guidance of a teacher. Corrects the task is a tool to learn basic and students will learn as they go through the answers and read or hear comments made by other students and teachers.

\section{METHOD}

Every researches has its own research method that is determined based on the purpose of the study. This research designed as a qualitative research. This method is also called naturalistic inquiry (Sugiyono, 2006: 14) because it studies a phenomenon in the natural way. According to Sukmadinata (2012:72), descriptive research is research that describe and explains the phenomenon, natural phenomenon or human phenomenon. Descriptive research examines activities, characteristic, change, relationship, similarities and differences with another phenomenon.

The researchers want to know about object, such as the nature of the object, the condition of the object, the number of the object, descriptive research is used by which he/she can explain the whole aspect of the object clearly and scientifically (Arikunto, 2006:25). Descriptive research will aim at providing as accurate an account as possible of what current practice is, how learners learn, how teachers teach, what classroom look like, at a particular moment in a particular place. The researchers collect the data, analyze them and draw a conclusion based on the data only.

In conclusion, this research is a descriptive qualitative research. This research is qualitative since the data are in the form of words. Meanwhile, the research is descriptive one since the researchers used descriptive method because they wanted to describe teacher's classroom management in teaching English at SMPN 5 Kota Serang and to explain the problems faced and teacher's classroom management skill by the English teacher.

Technique of Collecting Data

In qualitative research, the researchers themselves is the instrument, thus they should have the theory and wide insight about what will be researched. Then, to get deep understanding of the object of the research, the researcher should use some techniques of collecting the data simultaneously (Sugiyono, 2006:15). Therefore, there are two techniques used in this research namely observation and interview.

In the first research question "how do the English teacher apply their classroom management in teaching English?" the researchers used observation to answer the question and gain the data. The 
researchers use observation checklist during the observation which is adapted from Burden (1995). Observation is the instrument of collecting data which is used to organize individual behaviors or the process of the activity observed in real situation or simulation (Sudjana, 2005:109). In this method of collecting data, the researchers observed the classroom management do by a teacher in the class and the researchers tried to find some phenomena or activities during the process. In this part the researchers acted as the observer.

To triangulate the data from the observation and answer the second question, the researchers used unstructured interview. In this type of interview, they prepared what the questions are, before do the interview and new questions may emerge depend on the progress of interview and situation. It is possible to add new questions out of the questions list if the writer gets new information out of question list that will be arrange. After having the data from observation and already coding the result, the researchers organized the interview to all participant to make sure the data from observation will be valid.

\section{RESULT}

Observation had been done for 2 weeks to find out the English teachers classroom management strategies, which related to the first question that said "How do the English teachers apply their classroom management strategies in teaching English at SMPN 5 Kota Serang?" The observation was served in the form of observation checklist that divided into 5 categories; organization, behavioral consideration, instructional strategies, social climate, and physical arrangement. All of them adapted from Burden (1995) which was covered all part in classroom management. During the observation, the researchers recorded the teaching and learning activities into a written text to support the research. There were 2 English teachers available as the subject of the research. They were Teacher 1 (T1) and Teacher 2 (T2).

Table 1. The use of Classroom Management Strategy (T1)

\begin{tabular}{llll}
\hline No & Category & Total Use & Percentage \\
\hline 1 & Organization & 30 & $12 \%$ \\
\hline 2 & Behavioral consideration & 54 & $21 \%$ \\
\hline 3 & Instructional strategies & 45 & $18 \%$ \\
\hline 4 & Social climate & 40 & $16 \%$ \\
\hline 5 & Physical Arrangement & 13 & $5 \%$ \\
\hline
\end{tabular}

From the observation, the research found that $\mathrm{T} 1$ got higher score in observation checklist. It can be seen that the T1's score reached 181 points from 250 which was $72 \%$ from $100 \%$ in managing her classroom. In organization categories, the researchers found that she was excellent in organizing the classroom, it can be seen that $\mathrm{T} 1$ reached 30 points from 40 points .She generally could control the material. The direction for activities are clear which mean she managed the classroom well from opening until closing. If there was something unexpected, she can handle it with her other plan. She prepared the lesson before the class begin and distributed the lesson well. But for giving assignment, she prefer explained the assignment directly than written in the board so only students who sat in front row who heard the instruction.

In behavioral consideration she reached 54 points from 70 points. She gave positive rules to students in the classroom. She did the transitions activities well such as when she explained the lesson and communicate with students, she wasn't only focus in one side but in the other side. In the classroom, the students were regarding positive and negative consequence that they got if they break the rules. She always gave warn to student who disrupt other students in teaching learning process and who didn't bring a textbook in English lesson because of dispensation or other reason. So students understand about their consequent and can take responsibility for their behavior in 
the classroom. Even though there were any rules in the classroom, she still has problem in build students' positive behavior in the classroom, such as appreciate their friend or the teacher in front of them. She didn't give much attention in the last row, so there was many student who talked while the lesson held.

In instructional strategies, she reached 45 points from 70 points. The researchers found that the teacher used media when she made games. She also used whiteboard when she presented the material. She always monitored the lesson before and after she explain the material, instruction and examples. Although the strategies that she used in explain the material and example weren't update and interested to students. Whereas, the teacher used worksheet that have been provided by the school (LKS). The teacher also used textbook and whiteboard to tell the material. Sometimes she used questioning and feedback during the lesson. When she gave instructions, it was important for the students to check that the students have understood what the students were being asked to do. Based on observation this can be achieved either by asking a student to explain the activity after the teacher has given the instruction or by getting someone to show the other people in the class how the exercise works. Therefore, the teacher would ask to the students after the teacher told the material. When the students did not understand, the teacher would repeat it.

In social climate, she reached 40 from 55 which means she got $72 \%$ from $100 \%$. She has different style in understanding students and build relationship between teacher and students. She was really close and friendly to her students in the class. It was proved by her way in communication with students, listened what the students have and respect to other friends. Sometimes she gave humor while she explained the material, she gave students time to explain the material or answer the question by themselves, the relationship and effective communication between students was really good. Even though she didn't provide students with opportunities success, but she gave reward to students by saying "good" and gave applause. This was aimed to motivate students, in order that the students more active in learning and not to be fear of ridicule.

And for the physical arrangement, the researchers found that she reached 12 points from 15 points. She was good in making the classroom attractive, and seated the classroom arrangement. So students can see the material and the teacher all the time and vice versa. Even though there were any classroom which did not have good physical environment but she still could handle it. She asked students to work in group with 4-5 students in a group and the students choose to make a group with their friends who sat behind them.

The researchers found when $\mathrm{T} 1$ taught in $\mathrm{C}$ class she has a lot of problem in managing the class. It can be seen that many activities that teacher didn't do in C class. C class was her last class her taught. Many students want finished their school early and also many student from other class stand out the class so it made the situation did not conducive. The teacher didn't give many question, assignment to the students, and also made the classroom attractive so the students didn't interested much in the classroom.

Table 2. The use of Classroom Management Strategy

(T2)

\begin{tabular}{llll}
\hline No & Category & Total Use & Percentage \\
\hline 1 & Organization & 25 & $10 \%$ \\
\hline 2 & Behavioral consideration & 55 & $22 \%$ \\
\hline 3 & Instructional strategies & 44 & $17 \%$ \\
\hline 4 & Social climate & 39 & $16 \%$ \\
\hline 5 & Physical Arrangement & 12 & $5 \%$ \\
\hline
\end{tabular}


From the observation, the researchers found that $\mathrm{T} 2$ got low score than $\mathrm{T} 1$ in observation checklist. It can be seen that $\mathrm{T} 2$ 's score reached 180 from 250 which was $72 \%$ from $100 \%$ in managing classroom. In category of organization, T2 got 25 points from 40 points. From the observation he was good on develop his activities in teaching learning process and distributed the material effectively. But he got problem in prepared the material ahead of time before the class begin, didn't prepare other plan when there was any unexpected thing happened during the lesson and he still can't plan the time well. Because when the class was over, he still taught or gave some material to students. T2 didn't post the assignment clearly, he also explain the assignment directly without written on board.

In behavioral consideration categories, he reached 58 from 70 points. He was good in gave the discipline and develop student's behavior in the class. With the positive language, he gave positive rules and tended to give a treatment or warn when there were students who did not pay attention to his instruction. He called and came closer to the students who did not pay attention to the lessons or the students who disturb the other students. With that action students are clearly regarding positive and negative consequence and take responsibility for their behavior. And also he used proximity control to decrease inappropriate behavior such as against the teacher. His movement routines provide students with explicit steps for entering, exiting, and moving about the classroom.

In instructional strategies, he reached 46 from 70 points. He used small group and then independent work in his classroom. He was actually had a good way to explain the material, gave feedback to students and used questioning to get attention from the students. But he rarely used other example and material to make students more understand about the lesson. So it didn't make student interested because they just focus the example from the book. And when he show the slide of the material, the students still don't understand about the instruction from the teacher. The researchers found too that the instruction tool or method in teaching learning process weren't varied and also his example weren't up to date to make students interested.

In the social climate, he reached 39 from 55 Points. Similar with T1, T2 was friendly and positive attitude. He was good in make relationship with the students too. While explain the lesson sometime he gave motivation and with general wording refer generally to many different situations he saying "Be a good friend," and "Respect others". Sometimes he listen what students saying during the lesson and gave students change to explain about the material and interact with other friends. With positive approaches student got positive manner not only from the rules that teacher gave to the students but also from approaches itself. Even though he did not put some humor during the lesson. In physical arrangement, T2 got 12 from 15 points. He rarely made the classroom attractive for students. The physical environment wasn't interest for the students even though the teacher using media in teaching learning process. He always made classroom environment became tense. And he didn't ask student to seat the arrangement even if the students made into small group.

\section{Finding of interview}

In order to triangulate the data, the researchers organized the interview to make sure the data collected by the research was valid. The interview was organized in order to seek participants' response toward the problems happened to them and the solution they had been done during managing their classroom.

From the interview with $\mathrm{T} 1$ the researchers found that almost the problem that she got was classroom condition before the class begin. The teacher said every class has different situation. Not only in situation but also the environment itself make her to know the whole situation of each class. Teacher 1 also said that students' habit and discipline is the hard thing in managing classroom, because every students had different mood and there were still any students who disrupt and didn't listen what the teacher said to them. The students usually talked to their friends 
when the teacher talks too. It disturbed the teaching learning activity when the teacher explained the material. For the solution, the teacher warned the students when they disturbed the teaching learning process. The teacher also would give a punishment. The teacher punishes them by using treatment such as give task for them or ask them to mentions 30 words with the meaning.

From the interview, the research found that $\mathrm{T} 2$ has similar problem with $\mathrm{T} 1$. There was classroom condition, and it because every classroom has different situation. He also admitted that he still didn't make the classroom attractive. The solution he did observed more about the classroom, like environment and condition before class began. Beside the classroom condition, he also got problem in managing students' behavior. There were some students who didn't listen and pay attention to the material, and students who always disrupt the teaching learning process. Most of problem similar with teacher 1. But for teacher 2, the solution that he did to student who disrupt or misbehavior were shout their name, asked them to clean in front of the class or go out from the class.

\section{DISCUSSION}

From the findings of observation and interview above, the researchers found the teacher $1 \& 2$ has good organization in managing the classroom not only in direct the activities but also in giving material to the students. Even though they didn't post the assignment to the students clearly and gave them appropriate homework. Different with the Teacher 2, Teacher 1 didn't give much attend in behavioral consideration. According to Garret (2014:29) Classroom rules, though, are generally about overall conduct, whereas routines are much more specific to certain tasks and usually provide some direction about how these tasks should be accomplished, rather than seeking to prevent a particular type of behavior. Larson's theory (1992:92) stated that when a student is disrupting the class, first try some attention moves. Use direct eye contact or move closer to the student. It is also mentioned by Haddad (2006:43) stated that to control students' behavior, a teacher should stand close by rather than far away. For the students who were in and out without permission, she threatened to release students from class. While the teacher gave punishment to the students who did not pay attention to the lesson by giving warning that the teacher would reduce their score. It can be concluded that the teacher seemed to try to overcome the deviant behavior of students.

When the teacher gave instructions, it was important for the teachers to check that the students have understood what the teacher were being asked to do. According to Harmer (2008:38) there are two general rules for giving instructions: they must be kept as simple as possible, and they must be logical. Based on finding, this can be achieved either by asking a student to explain the activity after the teacher has given the instruction or by getting someone to show the other people in the class how the exercise works. Therefore, the teacher would ask the students after the teacher told the material. When the students did not understand, the teacher would repeat it.

To encourage the interaction between students, the teacher arranged the students to work in group or practice in pairs. It is supported by the theory of Scrinever (2005:67) who stated that teacher should encourage interaction between students rather than only between students and teacher, and teacher and students. Harmer (2008:24) also said that, good teachers are able to be flexible, using different class groupings for different activities. The teacher set the seating arrangement in orderly rows when the teachers told and presented the material use the board. As stated by Fauziati (2015:83), the arrangement depend on class size, number of students, type of chairs and tables in the room, goals of teaching, or type of activity to take place in the classroom.

Harmer (2008:41) also stated that Orderly rows imply teachers working with the whole class. In the first observation, the teacher arranges the students' seat in row when she asks students to work in group. The desks together make it easy for all students in the group to see each other and to discuss. Therefore, the teachers used separate table to set the students' seating arrangement. In 
the second observation, the teacher asked the students to made pair group. Harmer (2008:42) stated that pair work and group work are possible even when the class is seated in orderly rows, students can work with people next to them or in front of them or behind them.

\section{CONCLUSION}

There were several points that can be concluded as following description. It was revealed from the observation that $\mathrm{T} 1$ applied $72 \%$ and $\mathrm{T} 2$ applied $70 \%$ classroom management strategy. The teachers started to applying their classroom management strategies with prepared the material before entering the classroom first, then opening the teaching learning process, after opening the teachers explain and distribute the material efficiently. During the teaching and learning process, teachers give the students feedback and chance to speak or explaining the material, and the teachers used small group to make students more understand. The teachers not only presents the material clearly but also gave discipline, motivation and humors to them, so the teacher can build the relationship and positive attitude to the students. If there is any students who had misbehavior or disrupt the classroom the teacher always warned them or called her name, it make students more discipline in the classroom and respect to other friends. After the teachers explain the material, the teachers gave students assignment to review the material before they leaved the classroom.

Classroom condition and managing student misbehavior were the challenge that T1 and T2 always got in managing their classroom. Not only in physical environment from the classroom but also some students who didn't listen and pay attention to the material, and students who always disrupt the teaching learning process, don't listen what teacher said, and make noise in the classroom. Because each classrooms have differences physical environment, condition and also students' characters, so teacher should know all of the physical environment in each classroom.

To face the challenges, before teaching and learning process the teachers usually observing the classroom before. They would see the physical environment, such as dirty class or messy tools, if the classroom is dirty, they asked the students to clean up first. For the students who always disrupt the classroom, the teachers giving them warn such as called their name to make them focus in teaching and learning process, asking students to sit in front of the first line, giving them other assignment, and asking students to get out from the classroom.

\section{REFERENCES}

Arikunto, Suharsimi. (2006). Prosedur Penelitian Suatu Pendekatan Praktek. Jakarta: Rineka Cipta. Burden, R. Paul. (2000). Powerful Classroom Management Strategy. United Kingdom: Corwin Press, Inc.

Burden, P.R. (2010). Classroom management: Creating a successful learning community. (2th ed.). New York: John Wiley \& Sons

Emmer, E.T., \& Gerwels, M.C. (2006). Establishing classroom management for cooperative learning. Paper presented at the Annual Meeting of the American Educational Research

Association,Montreal, Canada.

Fauziati, Endang. (2015). Teaching English as a Foreign Language. Surakarta: Era Pustaka Utama.

Garret, Tracey. (2014). Effective of Classroom Management. Columbia University: Teacher College.

Good, Thomas and Brophy, Jere. ( 2003). Looking in Classroom: Ninth Edition. USA: Pearson Education Inc.

Haddad. Caroline. (2006). Practical Tips for Teaching Large Classes: A Teacher's Guide. Bangkok : UNESCO.

Harmer. Jeremy. (2008). How To Teach English. New edition. England : Longman.

Larson. Jo .Mary. (1992). Teaching English As A Foreign Language To Large, Multilevel Classes. USA : Peace Corps. 
Miles, Matthew B., A. Michael Huberman, Johnny Saldana. (2014). Qualitative Data Analysis: A Methods Sourcebook.Thousand Oaks, CA: Sage.

Marzano, R.J. (2003). Classroom Management That Works. Virginia US :ASCD.

Moloeng, Lexy J. (2007). Metode Penelitian Kualitatif. Bandung: PT Remaja Rosdakarya.

Palupi, Agata .R. (2013). Classroom Management Applied By the Eighth Grade Teacher in Teaching English in SMP Muhammadiyah 1 Surakarta in 2012/2013 Academic Year. Universitas Muhammadiyah Surakarta.

Arends, Richard. I. (2004). Learning to Teach. USA: McGraw-Hill.

Rudiyanto, Arif. (2014). Descriptive Analysis of Classroom Management Strategies of the Second Grade Students of SMP N 03 Tengaran Semarang. STAIN Salatiga

Scrivener. Jim. (2005). Learning Teaching: A Guidebook for English Language Teacher. 2nd ed. Malaysia : Macmillan Education.

Sudjana, Nana. (2005). Pengantar Penelitian Pendidikan. Jakarta: Bina RupA Aksara.

Sugiyono. (2006). Metode Penelitian (Pendekatan Kuantitatif, Kualitatif, dan RED). Bandung: Alfabeta.

Sukmadinata, Nana Syaodih. (2012). Metode Penelitian Pendidikan. Bandung: PT. Remaja Rosdakarya.

Weinstein, Carol and Romano, Molly. (2014). Elementary Classroom Management: Lesson from Research and Practice: Sixth Edition.USA: McGraw-Hill Education 